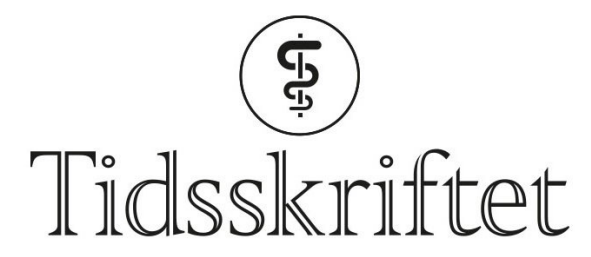

DEN NORSKE LEGEFORENING

\title{
Bedre prognose for lungekreftpasienter
}

FRA ANDRE TIDSSKRIFTER

ØYVIND STOPLE SIVERTSEN

Tidsskriftet

Mer enn én av fire kvinner lever fem år etter å ha fått lungekreftdiagnose - en kraftig forbedring fra tidligere.

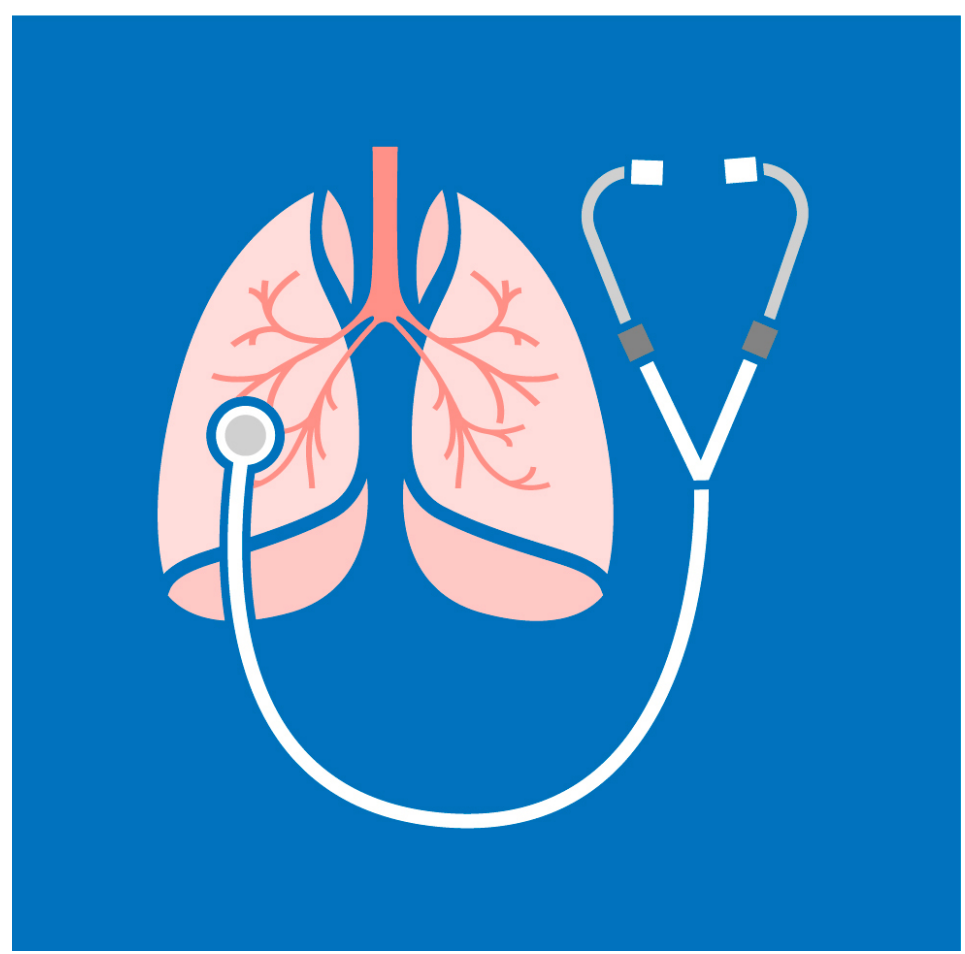

Illustrasjonsfoto: newannyart/iStock

Lungekreft er den fjerde hyppigste kreftformen i Norge og den hyppigste årsaken til kreftdød for begge kjønn. Hvert år dør flere enn 2 ooo nordmenn på grunn av lungekreft. Kan store endringer i diagnostikk og behandling ha endret prognosen?

I en studie som nylig er publisert i tidsskriftet Lung Cancer, brukte en norsk forskergruppe kreftregisterdata for å studere endringer i insidens og overlevelse fra 2000 til 2016 (1).

I denne perioden fikk 44825 personer diagnosen lungekreft i Norge. Insidensen $ø$ kte med $49 \%$, mens prevalensen $ø$ kte med $136 \%$. I 2016 var $50 \%$ av tilfellene adenokarsinomer, mens gruppen «ikke-småcellet lungekreft, ikke nærmere spesifisert» gikk ned fra $24 \%$ til $13 \%$. 
Andelen med metastaser på diagnosetidspunktet var relativt stabil. Viktigere var at median overlevelse for lungekreft mer enn doblet seg - fra 6,5 måneder til 14,3 måneder for kvinner og fra 5,4 måneder til 11,4 måneder for menn. Relativ femårsoverlevelse økte fra $16 \%$ til $26 \%$ og fra $9 \%$ til $22 \%$ for henholdsvis kvinner og menn. Spesielt hadde gruppen med ikkeoperabel lokalisert sykdom en markert forbedring i femårsoverlevelse.

- Både PET-CT og ultralydveiledet bronkoskopi ble innført rundt 20oo, forteller Odd Terje Brustugun, som er overlege ved Onkologisk seksjon, Drammen sykehus, og studiens førsteforfatter.

- Samtidig ble nye målrettede legemidler og nye strålebehandlingsteknikker som stereotaksi tatt i bruk. Den viktigste årsaken til den økte overlevelsen ved lokalisert sykdom er trolig innføring av stereotaktisk strålebehandling, og immunterapi vil forhåpentlig kunne forbedre overlevelsen ytterligere i fremtiden, sier Brustugun.

Studien er et samarbeid mellom forskere fra Kreftregisteret og styret i Norsk lungekreftgruppe - en sammenslutning av lungkreftinteresserte leger fra ulike spesialiteter og fra hele landet.

\section{LITTERATUR:}

1. Brustugun OT, Grønberg BH, Fjellbirkeland L et al. Substantial nation-wide improvement in lung cancer relative survival in Norway from 200o to 2016. Lung Cancer 2018; 122: 138 - 45.

[PubMed][CrossRef]

Publisert: 27. september 2018. Tidsskr Nor Legeforen. DOI:10.4045/tidsskr.18.0612

(C) Tidsskrift for Den norske legeforening 2020. Lastet ned fra tidsskriftet.no 